\title{
I. GREETINGS BY ACADEMICIAN B. E. PATON, THE PRESIDENT OF THE NATIONAL ACADEMY OF SCIENCES OF UKRAINE
}

\section{B. E. Paton}

To the participants of the Anniversary General Meetings of the Mechanics Division of the National Academy of Sciences of Ukraine, devoted to the 100th Anniversary of the foundation of the S. P. Timoshenko Institute of Mechanics

Dear participants of the General Meetings of the Mechanics Division!

November, 2018 was 100 years since the S. P. Timoshenko Institute of Mechanics was founded.

The Institute has always played a special role in the development of Ukrainian and world mechanics and formation of areas of research. The creation of the world-famous school of nonlinear mechanics brightly illustrates the aforesaid.

The world scientific community is well aware of the achievements of the Institute in developing new standards of strength, determining the physical and mechanic properties of rock, developing a nondestructive method for the determination of the mechanical properties of wood, studying the strength of bridge elements and developing their failure criteria, formulating the statistical theory of fatigue fracture, solving problems of dynamic strength of military structures. The Institute has developed the theory and methods of designing plates and shells of revolution, studied the energy dissipation in turbine blades, discovered the new phenomenon of absorption fatigue of metals, suggested a method for mechanical tests of hard and fragile steels at different temperatures, developed a new method of evaluating the wear resistance of steels from the physical and mechanical characteristics of the surface layer.

The Institute developed new research areas related to composites, thermoplasticity, numerical methods of the theory of shells, the nonlinear theory of vibrations of solids, etc. The findings in these areas are applied in many industries, and engineering practice of leading research and development institutions, and design offices.

Today, the Institute is studying a wide range of aspects in elasticity and thermoplasticity, theory of shells, stress concentration, fatigue, strength, and plasticity of materials and structural elements, collaborating with such leading state-owned enterprises, including and Pivdenne Design Office, Antonov Design Office, and others.

The scientists of the S. P. Timoshenko Institute of Mechanics by their selfless work represent Ukraine in the avant-garde of the world science and technology*.

I am sure that the mechanicians of the Academy will overcome decently all difficulties we now face, and in the future will gain a lot of significant results to enhance the economy and strengthen the defense potential of our country.

I heartedly wish you all good health, creative findings for the sake of our people, our Ukraine.

President,

National Academy of Sciences of Ukraine, NASU

* Nine of the 12 departments at the S. P. Timoshenko Institute of Mechanics, including the institute itself, are of category A. 